\title{
An Assessment of Workplace Skills Acquired by Students of Vocational and Technical Education Institutions
}

\author{
Ab Rahim Bakar ${ }^{1}$, Shamsiah Mohamed ${ }^{2} \&$ Ramlah Hamzah $^{1}$ \\ ${ }^{1}$ Faculty of Educational Studies, Universiti Putra Malaysia, Malaysia \\ ${ }^{2}$ Faculty of Science, Universiti Putra Malaysia, Malaysia \\ Correspondence: Ab Rahim Bakar, Faculty of Educational Studies, Universiti Putra Malaysia, Malaysia. E-mail: \\ abrahimbakar@yahoo.com
}

Received: September 4, 2013

Accepted: October 9, $2013 \quad$ Online Published: October 11, 2013

doi:10.5539/ies.v6n11p15

URL: http://dx.doi.org/10.5539/ies.v6n11p15

\begin{abstract}
This study was performed to identify the employability skills of technical students from the Industrial Training Institutes (ITI) and Indigenous People's Trust Council (MARA) Skills Training Institutes (IKM) in Malaysia. The study sample consisted of 850 final year trainees of IKM and ITI. The sample was chosen by a random sampling procedure from a population of 2520 students from both institutions. Trainees' employability skills were measured using a 40 item questionnaire adapted from the Secretary's Commission on Achieving Necessary Skills (SCANS) report. In general, the majority of the trainees possessed a moderate level of employability skills $(\mathrm{Mean}=3.88, \mathrm{~S} . \mathrm{D}=.49)$. Their basic skills were at the moderate level (Mean= 3.83, S.D= .9); thinking skills $(\mathrm{Mean}=3.73, \mathrm{~S} . \mathrm{D}=.56)$; source skills (Mean= 3.83, S.D= .57); informational (Mean= 3.61, S.D= .76); interpersonal $(\mathrm{Mean}=3.92, \mathrm{~S} . \mathrm{D}=.57)$; technical and system skills (Mean=3.81, $\mathrm{S} . \mathrm{D}=.67)$; and self-qualities $(\mathrm{Mean}=4.14, \mathrm{~S} . \mathrm{D}=.55)$. There were no significant differences of employability skills between trainees from IKM and ITI in term of gender, work experience, and between courses.
\end{abstract}

Keywords: employability skills, TVET trainees, vocational education

\section{Introduction}

Of late, there has been global a shift in educational and labor policies that requires institutes of higher learning to shoulder the responsibility for the employability of their graduates. In Malaysia, this responsibility is one of the Key Performance Indicators (KPI) of higher learning institutions. Gone are the days when employers snap up graduates even before they finish their final examinations. Educational institutions in Malaysia must now make every effort to ensure that their graduates are employed within six months after graduation, and are required to set out initiatives to make their graduates employable.

In order to remain relevant in the job market, workers must constantly adapt to changes and evolving requirements in the work environment, including the use of new and emerging technologies (Butterwick \& Benjamin, 2006). As said by Opengart \& Short (2002), job security orientation has changed to employability security orientation. Thus, all graduates must have the skills not only to get a job, but also to remain employable in the future. Globalization and the extensive use of ICT at the workplace has led to the emergence of a new economy (Boutin, et al, 2009) which demands a new set of criteria from potential employees in order for them to be successful on the job. The new economy requires teamwork and the abilities to cooperate in unclear environments, to solve problems, to deal with non-routine process, to communicate effectively, and to see the workplace environment in a broader context. Workers must function beyond what is expected of them, and must possess those skills that they need to survive in the changing economy.

In addition to the changes in the global economy, the use of new technologies has made many existing skills obsolete, thus requiring workers to constantly update their knowledge and skills. These changes, both in terms of technological advances and organizational restructuring, coupled with slow economic development have resulted in high unemployment among youths in many countries. Based on ILO report (ILO, 2010), youth account for $25 \%$ of the world working age population, yet they account for one-half of the global unemployment. In fact, unemployment among youth was nearly three times higher than among adults in 2009 (13\% compared to $4.9 \%$ ), 
and in 2011, the unemployment rate among youth was projected to be about $12.7 \%$ (ILO, 2010). Thus, we need to help youth acquire the employability skills that they need to enter the workforce.

With employability skills in hand, not only will they be employable by corporations or firms, but they should also be able to generate jobs for others through creation of small businesses. In fact, small businesses contribute to a large extent of economic development with the creation of many jobs. According to Edmiston (2007) between 1990 and 2003, the small-business sector was responsible for $79.5 \%$ of US job creation. Robbins, Pantuoso, Parker, and Fuller (2000) found that U.S. states with higher percentages of very small businesses (20 employees or less) have a more productive workforce and higher levels of GDP growth than states with lower levels of very small businesses. Thus, creating small businesses may eliminate some of the unemployment issues among youth, but to be able to create a new business one has to have the desired skills similar to what one needs to be employed.

\subsection{What is Employability Skill?}

Employability skills refer to non-technical skills needed to effectively function as an employee and work for the betterment of oneself and the organization. Yorke (2006) defined employability skills as a set of skills, knowledge, and personal attributes that makes an individual more likely to secure and be successful in their chosen occupation(s), to the benefit of themselves, the workforce, the community, and the economy. The Australian Chamber of Commerce and Industry (ACCI) and the Business Council of Australia (BCA) view employability skills as "skills required not only to gain employment, but also to progress within an enterprise so as to achieve one's potential and contribute successfully to enterprise strategic directions" (ACCI and BCA, 2002). Based on a review of related literature, Taylor (2007) concluded that it is not hands-on, job-related skills and competencies that are being sought by employers, but a complex of attitudinal dispositions and affective traits - those that youth, in particular, are said to lack. ACCI and BCA (2002) categorized employability skills into two categories: attributes and skills. Examining these two categories, one may come to a conclusion that the attributes need by the employers come from within an individual. Regardless of the amount of training given, one may not acquire these attributes. It is built in the person and training can enhance these attributes.

\subsection{The Study on Employability Skills}

According to Mansfield (2001), the concept of "employability" was first proposed by Beveridge in the United Kingdom in 1909. Since then, it has commanded a central place in the U. K. and many other European states (McQuid \& Linsay, 2004). Nowadays, employability is the magical word that is getting a serious attention by all nations. A landmark study on employability skills was conducted in the U. S by National Center on Education and the Economy in 1990, due to the declining skills of graduates and a possible global and long-term economical impact. From that study, the United States Department of Labor published The Secretary's Commission on Achieving Necessary Skills, or SCANS. Seven main categories of employability skills were identified in the report: basic skills; personal qualities; thinking skills; resource management; information skills; interpersonal skills; system management and technology use. The SCANS skills have subsequently been used as an organizing framework for curricula in high schools across the United States and in the design of a variety of government-sponsored job-training programs such as those funded through Job Corps, the Job Training Partnership Act, and the School-to-Work Opportunities Act (Bates \& Phelan, 2002). Recently, Mashburn (2009) analyzed the 4-H curriculum in the US to determine the extent to which 4-H curricula included SCANS competencies. Based on the study, the author suggested that curriculum developers should increase the inclusion of SCANS competencies in 4-H curriculum.

Other studies on employability skills have been conducted in Canada, Australia, and the United Kingdom. According to McLaughn (1995), in the late 1980s and early 1990s, employers and educators in Canada voiced concern over the fact that Canadian youths were underprepared to participate in paid work. The Board then came up with Employability Skill Profile in 1992 after a series of meeting with 100 human resource professionals. In Australia in the early 1990s, the Mayer Committee was formed to develop a set of key competencies, formalized as the "Employability Skills Framework." In the UK, "key skills" describes generic and transferable skills that people could learn and develop in a wide variety of situations. This contrasts with "essential skills" which are fundamental for learners in achieving their full potential and participation in society.

\subsection{TVET in Malaysia}

In its national development plan for 2011-2015, the Malaysian government set out goals to become recognized as a high-income economy and to increase the average per-capita income level from its current level of USD \$7000 to $\$ 20,000$. In order to accomplish this goal, the country needs a highly skilled workforce. As with many developing nations, Malaysia employs a Technical Vocational Education and Training (TVET) system, as laid out by UN 
(2006), to supply the bulk of worker skills development and produce employable graduates. TVET is essential for enhancing global economic competitiveness, social inclusion, poverty reduction and sustainable development (UIS, 2006).

In 2009, Malaysia's skilled labour force stood at 28\%, well below the average of $37.6 \%$ of other OECD nations; Nor Mohammed Yakcop, Minister in the Prime Minister's Department, has stated a target goal to raise that percentage of highly-skilled labours to $40 \%$. Many different government agencies take part in ensuring Malaysia has the required number of high-skilled workers. For example, there are 23 industrial training institutes (ITI) under the auspices of the Ministry of Human Resource with a student population of 7780 as of 2011. These institutes offer various types of technical courses both at the certificate and diploma levels with the purpose of producing high-skilled workers needed by the industry. There are 20 MARA skills training institutes (IKM) under the auspices of the Ministry of Rural Development. IKM has a student population of 9803 as of 2013. Similar to the ITI, IKM also offer courses in technical areas both at the certificate and diploma level and the types of courses offered are almost similar for both ITI and IKM. As TVET is expected to play a big role in reaching this goal, Malaysia must significantly increase enrolment in TVET programs. No one agency is responsible for the delivery of TVET in Malaysia and many different approaches and curricula are employed among the various agencies that offer such training. Thus, there is a need to streamline implementation and ensure that the programs work efficiently in order to reach the end goal.

\subsection{Objectives}

The main objective of the study was to identify the employability skills that have been acquired by technical and vocational students in Malaysia. We also tested four hypotheses:

\subsection{Hypotheses}

In this study we tested four hypotheses.

$\mathrm{H}_{\mathrm{O} 1}$ : The employability skills of ILP and IKM trainees do not significantly differ.

$\mathrm{H}_{\mathrm{O} 2}$ : The employability skills of trainees do not differ as a function of gender.

$\mathrm{H}_{\mathrm{O} 3}$ : The employability skills of trainees do not differ as a function of program they enrolled in.

$\mathrm{H}_{\mathrm{O} 4}$. The employability skills of trainees do not differ as a function of work experience.

\section{Methodology}

\subsection{Sample}

At the time of the study, there were 13 IKM and 14 ITI throughout Malaysia with a total of 2520 final year students. We employed a simple random sampling procedure to select a sample of 850 final year trainees of the 27 institutes. Data were gathered with helps from enumerators who went to the institutes and administered the instrument to trainees. All 850 trainees returned the completed instrument.

\subsection{Measures}

The instrument we used for the study consisted of 2 sections; demographics and employability skills. To measure the employability skills of the trainees we used the instrument developed by the Secretary's Commission on Achieving Necessary Skills (SCANS). The Commission categorized the skills into seven specific skills: basic skills; personal qualities; thinking skills; resource management; information skills; interpersonal skills; system management and technology use. While there are many employability skills measure, most focus on the same or similar themes as the SCANS, so we are confident of its validity as a measure.

To ensure its reliability for use with our sample, we pilot tested it using a sample of 60 trainees from one of the institutes. The estimated reliability coefficient was 0.94 . The reliability of each specific skill was: basic skills $(\alpha=$ $0.79)$; personal qualities $(\alpha=0.93)$; thinking skills $(\alpha=0.90)$; resource management $(\alpha=0.82)$; information skills $(\alpha=0.85)$; interpersonal skills $(\alpha=0.83)$; system management and technology uses $(\alpha=0.85)$.

\section{Findings}

\subsection{Demographic Characteristics of Respondents}

A majority of respondents $(72 \%)$ were male, while $28 \%$ were female; this ratio is quite common in many parts of the world. Their ages ranged between 19 to 29 years old. Almost $91 \%$ of them were in the program at the certificate level, while $9 \%$ were at the diploma level. Students were enrolled in an array of programs: electrical (23.6\%); electronic (17.7\%); mechanical (32.2\%); automotive (7.1\%); and building (19.6\%). 
Nearly $89 \%$ of the respondents indicated that their program of study requires them to undergo a 12 -month program of industrial training, yet at the time of our survey, $62 \%$ of them had not done so. That said, $63 \%$ indicated that they had previous work experience, and were employed before their current course of studies. When asked about their plans after graduating, $71 \%$ plan for further study, while the remainders intend to enter the workforce immediately after graduation.

\subsection{Employability Skills of Respondents}

Using the SCAN instrument, we asked the respondents to what extent they believed they had acquired the skills needed by employers. Their mean response provided a score of 3.88, with a standard deviation of 0.49 . The mean score for all 7 components of the skills are presented in Table 1.

Table 1. Means and standard deviations of employability skills acquired by the respondents

\begin{tabular}{lll}
\hline Skills & Means & SD. \\
\hline Basic skills & 3.83 & .59 \\
Personal qualities & 4.14 & .55 \\
Thinking skills & 3.73 & .56 \\
Resource management & 3.83 & .57 \\
Information skills & 3.61 & .76 \\
Interpersonal skills & 3.92 & .57 \\
System management and technology uses & 3.81 & .67 \\
Overall mean & 3.88 & .49 \\
\hline
\end{tabular}

\subsection{Hypotheses Tested}

We tested four hypotheses to determine if employability skills differ among trainees as a function of selected variables.

$H_{O I}$ : The employability skills of ITI and IKM trainees do not significantly differ.

We found that employability skills of trainees from both institutions did not differ $\left(\mathrm{t}_{(848)}=.515, \mathrm{p}>0.05\right)$. Their mean scores were similar, as shown in Table 2 . Their employability skills were moderately high.

$H_{O 2}$ : The employability skills of trainees do not differ as a function of gender.

We found that the skills are not a function of gender $\left(\mathrm{t}_{(848)}=-.138, \mathrm{p}>0.05\right)$. Regardless of the gender, trainees' employability skills were similar and they were moderately high.

$H_{O 3}$ : The employability skills of trainees do not differ as a function of program they enrolled in.

We found that the employability skills of trainees differed as a function of program enrolled $\left(\mathrm{F}{ }_{(4,845)}=2.51\right.$, $\mathrm{p}=.04)$. Trainees enrolled in the automotive program had the highest mean score, followed by trainees in the electrical program. Trainees in other programs obtained similar mean scores.

$H_{O 4}$. The employability skills of trainees do not differ as a function of work experience.

The trainees' employability skills also did not differ as a function of work experience. Regardless of whether trainees have worked prior to their enrollment at the institutes, their employability skills were almost similar ( $t$ $\left.{ }_{(845)}=-.536, \mathrm{p}>0.05\right)$.

Table 2. Means and standard deviations of employability skills by institution, gender, program enrolled, and work experience

\begin{tabular}{llll}
\hline Variables & Means & SD & Test \\
\hline Institution & & .39 & \\
$\quad$ IKM & 3.86 & .43 & $\mathrm{t}_{(848)}=.515, \mathrm{p}>0.05$ \\
$\quad$ ITI & 3.85 & .40 & \\
Work Experience & & .42 & $\mathrm{t}_{(845)}=-.536, \mathrm{p}>0.05$ \\
$\quad$ Yes & 3.85 & & \\
$\quad$ No & 3.86 & & \\
Gender & & & \\
\hline
\end{tabular}




\begin{tabular}{llll}
\hline Male & 3.85 & .39 & $\mathrm{t}_{(848)}=-.138, \mathrm{p}>0.05$ \\
Female & 3.86 & .46 & \\
Program enrolled & & & \\
Mechanical & 3.85 & 0.40 & $\mathrm{~F}_{(4,845)}=2.51, \mathrm{p}=.04$ \\
Electrical & 3.91 & 0.42 & \\
Building & 3.81 & 0.40 & \\
Electronic & 3.82 & 0.42 & \\
Automotive & 3.95 & 0.40 & \\
\hline
\end{tabular}

\section{Discussion}

The basic objectives of TVET education are to produce functional graduates with knowledge and skills, both in terms of technical abilities and in terms of employability skills. This study illustrates that the employability skills level of technical and vocational trainees were at the moderate level and can be improved further. People are natural resources that can propel any country to a greater height if they have the skills that enable them to manipulate their technical knowledge and skills. Most people attend educational institution for one main reason: to get a qualification or a diploma in a certain area. But according to Brown and Hesketh (2004) and Lafer (2004), qualification is only part of the answer for employability, and soft skills play a key role in the workforce at both the top and bottom end of labor market. It is believed that without the employability skills there will be a decline in competitiveness, diminishing economic return, and a bleaker future for all. Thus, it is important for our TVET institution to develop and enhance students' employability skills to meet the demand by employers. In order to reach stated development goals and become recognized as an industrialized nation by 2020, Malaysia must ensure that technical students have high employability skills.

Having employability skills will ease the transition from school to work, thus reducing the unemployment rate among high school graduates. Due to the importance of these skills, students should be given opportunities to acquire them, but not necessarily by developing a separate subject. Employability can be infused and integrated across curriculum using different teaching approaches. For example, project-based learning, case studies, problem-based learning, teamwork activities, and student leadership development activities can all be utilized to provide students with the necessary skills. Thus, we suggest that all TVET institutions should consider designing the curriculum with the objective of developing and enhancing students' employability skills.

\section{Reference}

Australian Chamber of Commerce \& Industry and the Business Council of Australia. (2002). Employability skills for the future. Canberra: Department of Education, Science and Training.

Australian Chamber of Commerce \& Industry. (2002). Employability skills - an employer's perspective: Getting what employers want out of the too hard basket. Barton, ACT: Australian Chamber of Commerce \& Industry.

Australian Chamber of Commerce and Industry and Business Council of Australia. (2002). Report commissioned by Department of Education, Science and Training. Retrieved from http://www.acci.asn.au/text_files/reports/Employability_skills.pdf

Bates, R. A., \& Phelan, K. C. (2002). Characteristics of a globally competitive workforce. Advances in Developing Human Resources, 4(2), 121-132. http://dx.doi.org/10.1177/1523422302004002003

Boutin, F., Chinien, C., Moratis, L., \& Van Baalen, P. (2009). Changing Workplace Requirements: Implications for Education. In R. Maclean, \& D. Wilson (Eds.), International Handbook of Education for the Changing World of Work, Part II, Section 1, 81-96. http://dx.doi.org/10.1007/978-1-4020-5281-1_5

Brown, P., \& Hesketh, A. (2004). The Mismanagement of talent. Oxford: Oxford University Press. http://dx.doi.org/10.1093/acprof:oso/9780199269532.001.0001

Brown, P., Hesketh, A., \& Williams, S. (2002). Employability in a Knowledge-Driven Economy. Working Paper Series Paper 26, School of Social Science, Cardiff University. Retrieved from http://www.cf.ac.uk/socsi/publications/workingpapers/

Butterwick, S., \& Benjamin, A. (2006). The road to employability through personal development: A critical analysis of the silences and ambiguities of the British Columbia (Canada) life skills curriculum. International Journal of Lifelong Learning, 25(1), 75-86. http://dx.doi.org/10.1080/02601370500309543 
Edmiston, K. (2007). The role of small and large businesses in economic development. Economic Review, Federal Reserve Bank of Kansas City, 92, 73-97. Retrieved from http://www.kansascityfed.org/PUBLICAT/ECONREV/PDF/2q07edmi.pdf

Ghulam R. Nabi. (2003). Graduate employment and underemployment: Opportunity for skill use and career experiences amongst recent business graduates. Education + Training, 45(7), 371-382. http://dx.doi.org/10.1108/00400910310499947

ILO. (2010). Global Employment Trends for Youth 2010. International Labour Office, Geneva. Retrieved from http://www.ilo.org/public/portugue/region/eurpro/lisbon/pdf/relatorio_get.pdf

Lafer, G. (2004) What is 'skill'? Training for discipline in the low-wage labour market. In Warhurst, C., Grugulis, I., \& Keep, E. (Eds.), The Skills that Matter. Basingstoke: Palgrave.

Leconte, P. J. (2006). The Evolution of Career, Vocational, and Transition Assessment: Implications for the Summary of Performance. Career Development for Exceptional Individuals, 29(2), 114-124. http://dx.doi.org/10.1177/08857288060290020301

Mashburn, D. E. (2009). Secretary's commission for the achievement of necessary skills (scans) competencies within 4-H curricula. Unpublished doctoral thesis, University of Florida, Gainsville: Florida. Retrieved from http://etd.fcla.edu/UF/UFE0024670/mashburn_d.pdf

McLaughlin, M. A. (1995). Employability Skills Profile: What Are Employers Looking For? ED399484 1995-00-000042098042000316100

McQuaid, R., \& Lindsay, C. (2005). The concept of employability. Urban Studies, 42(2), 197-219. http://dx.doi.org/10.1080/0042098042000316100

National Commission on Excellence in Education. (1983). A Nation at Risk. Washington, DC: U.S. Government Printing Office.

OECD. (2001). Competencies for the Knowledge Economy. Education Policy Analysis, Paris, OECD.

Opengart, R., \& Short, D. (2002). Free agent learners: The new career model and its impact on human resource development. International Journal of Lifelong Education, 22(1), 220-233. http://dx.doi.org/10.1080/02601370210127837

Robbins, D. K, Pantuosco, L. J, Parke, D. F., \& Fuller, B. K. (2002). An ampirical assessment of the contribution of small business employment to U. S. State economic performance. Small Business Economics, 15(4), 293-302. http://dx.doi.org/10.1023/A:1011129728483

Saunders, V., \& Zuzel, K. (2010). Evaluating employability skills: Employer and student perceptions. Bioscience Education, 15. Retrieved from http://www.bioscience.heacademy.ac.uk/journal/vol15/beej-15-2.pdf

Taylor, A. (2007).What employers look for: The skills debate and the fit with youth perceptions. Journal of Education and Work, 18(2), 201-218. http://dx.doi.org/10.1080/13639080500085984

The Commission on the Skills of the American Workforce. (1990). America's Choice: High Skills or Low Wages. Rochester, NY: National Center on Education and the Economy.

U. S. Department of Labor. (1991). What work requires of schools: A SCANS report for America 2000. Secretary's Commission on Achieving Necessary Skills. Washington, DC.

UNESCO. (2005). Global Education Digest. Paris. Retrieved from http://www.uis.unesco.org/template/pdf/ged/2005/ged2005_en.pdf

UNESCO Institute of Statistics (UIS). (2006). Participation in Formal Technical and Vocational Education and Training Programmes Worldwide: An Initial Statistical Study. UNEVOC (UNESCO International Centre for Technical and Vocational Education and Training. Bonn: Germany.

Yorke, M. (2006). Employability in Higher Education: What it is - what it is not. York: The Higher Education Academy.

\section{Copyrights}

Copyright for this article is retained by the author(s), with first publication rights granted to the journal.

This is an open-access article distributed under the terms and conditions of the Creative Commons Attribution license (http://creativecommons.org/licenses/by/3.0/). 